\title{
A CIÊNCIA NOS MEIOS DE COMUNICAÇÃO DE MASSA: divulgação de conhecimento ou reforço do imaginário social?*
}

\section{The Science in mass communication: popularization of knowledge or social reinforcement of the imaginary?}

\author{
Márcia Reami Pechula ${ }^{1}$
}

\begin{abstract}
Resumo: O texto descreve a crise teórico-metodológica da ciência moderna instaurada no século XX, contraposta ao imaginário social presente na recepção da ciência divulgada pelos meios de comunicação de massa. A descrição demonstra que há um paradoxo entre a produção do conhecimento científico, forjado nos centros e instituições científicas, e a visão geral daqueles que recebem as informações científicas via meios de comunicação de massa. Para tanto, o trabalho estrutura-se em quatro etapas: $1^{\circ}$ ) descreve o processo da crise teórico-metodológica da ciência no século XX, no âmbito acadêmico; $2^{\circ}$ ) analisa a formação dos elementos constitutivos do imaginário social, sob a perspectiva sociológica; $3^{\circ}$ ) analisa as condições da ciência como informação nos meios de comunicação de massa; $4^{\circ}$ ) demonstra a veiculação das informações científicas dos meios de comunicação de massa, exemplificada pela leitura da revista Superinteressante.
\end{abstract}

Palavras-chave: Ciência. Imaginário social. Meios de comunicação de massa.

\begin{abstract}
The text describes the context of the theoretical-methodological crisis of modern science established in the XX century as opposed to the present social imaginary in the reception of science disclosed in mass communication. The analysis demonstrates that there is a paradox between the production of scientific knowledge forged in scientific institutions and the general vision of those that receive the scientific information through means of mass communication. The work has four consecutive themes: firstly, it describes the process of the theoretical-methodological crisis of science in the XX century in the academic realm; later on, it analyzes the formation of the constituent social elements of the imaginary, from a sociological perspective; in the third section, it analyzes the conditions of science as information within mass communication. And, lastly, it describes the means of mass communication with its scientific popularization, exemplified by the reading of the magazine Superinteressante.
\end{abstract}

Key words: Science. Social imaginary. Means of mass communication.

\footnotetext{
*Temática apresentada na 27 Reunião Anual da Anped, Caxambu, de 21 a 24 de novembro de 2004, GT Educação e Comunicação.

${ }^{1}$ Doutora em Comunicação e Semiótica; professora, Departamento de Educação, Instituto de Biociências, Unesp - Rio Claro. Rio Claro, SP. <mreami@rc.unesp.br>
} 
Pechula, M. R.

\section{Introdução}

A ciência moderna, cujo apogeu é alcançado com a teoria positivista do século XIX, tem sua identidade orientada para a dominação e a manipulação dos fenômenos, e confere ao homem poder efetivo sobre a natureza e a imposição do saber dominante. Tal saber sofre um impulso nas primeiras décadas do século XX, com o avanço das descobertas científicas que proporcionam o desenvolvimento da tecnologia, dando início à chamada "revolução tecnológica". Entretanto, tais descobertas ampliam e extrapolam o estatuto da teoria e método positivistas. Simultaneamente, os meios de comunicação permitem que a divulgação científica extrapole os muros das universidades e instituições de pesquisas e torne-se acessível à população em geral. Amparado por estas perspectivas, o texto reflete sobre a recepção da ciência construída e transmitida por estes dois "veículos" de conhecimento e informação.

\section{A ciência no século $X X$}

O conhecimento científico não é único, nem absoluto, entretanto, dada sua característica básica, sustentada pela teoria científica, é o mais respeitável no campo acadêmico. Para Hawking e Mlodinow (2005), uma teoria científica é um modelo; é algo "que existe apenas em nossas mentes e não tem qualquer outra realidade [...]". Mesmo tendo clareza do limite que essa condição implica, a teoria científica é o critério maior de validação do conhecimento científico. Assim, a credibilidade do conhecimento sustenta-se na força de sua teoria. Uma teoria é boa quando: "[...] descreve com exatidão uma grande classe de observações com base em um modelo que contenha somente poucos elementos arbitrários e faz previsões bem definidas sobre os resultados de observações futuras” (p. 23). Essa assertiva está de acordo com o modelo de ciência posto pela modernidade, o qual assevera que a ciência é o conhecimento capaz de explicar e compreender a natureza objetivamente.

Na primeira metade do século XX, ocorreram, no campo científico, grandes descobertas: a Teoria da Relatividade Geral (apresentada por Einstein em 1915), e as pesquisas observacionais de Hubble (que, na década de 1920, permitiram verificar que o universo é composto por inúmeras galáxias que se distanciam continuamente umas das outras em todas as direções do espaço cósmico), no campo da Física; a crescente credibilidade e desenvolvimento da Teoria da Seleção Natural das Espécies, de Darwin (1981) (que publica a obra $A$ Origem das Espécies em 1859), no campo da Biologia, possibilitaram, certamente, as maiores transformações científicas desse século, dentre as quais se destacam a teoria do big-bang e a descoberta do DNA (esta permitiu o avanço da zoologia comparada, da botânica, da anatomia comparada, da antropologia e da biologia genéticas) (GLEISER, 1997; BUICAN, 1990).

No citado período, abre-se, no campo acadêmico e intelectual, um amplo debate que destina-se a reconstruir (ou re-significar) os moldes e a credibilidade do conhecimento científico em suas bases modernas. O conhecimento científico, apesar de continuar como representante máximo da verdade, passa por uma crise, sobretudo em seu aspecto teórico-metodológico, provocando o surgimento do processo chamado de "multiplicidade teórico-metodológica". Tal situação resulta numa condição ambígua: ao mesmo tempo em que monopoliza a verdade, ampliam-se as teorias e metodologias diferentes em disputa desse monopólio. Dá-se 
início a uma verdadeira "guerra das ciências" (STENGERS, 1996), em meio à qual as questões especulativas (míticas e religiosas) se alternam: ora são desprezadas, ora são empregadas. Esse processo é chamado de pós-moderno, por vários teóricos da filosofia, da sociologia, da antropologia, entre outras áreas. Autores como Rouanet (1987), Jameson (1996) e Santos (1987) destacam-se na discussão sobre essa questão.

Segundo Rouanet (1987, p. 12):

depois de Marx e Freud, não podemos mais aceitar a idéia de uma razão soberana, livre de condicionamentos materiais e psíquicos. Depois de Weber, não há como ignorar a diferença entre uma razão substantiva, capaz de pensar fins e valores; e uma razão instrumental cuja competência se esgota no ajustamento de meios a fins. Não é possível escamotear o lado repressivo da razão a serviço de uma astúcia imemorial, de um projeto imemorial de dominação da natureza e sobre os homens. Depois de Foucault, não é lícito fechar os olhos ao entrelaçamento do saber e do poder.

Dessa forma, a pós-modernidade aparece como a substituição de conceitos, métodos e valores. $\mathrm{Na}$ esfera econômica, a industrialização é substituída pela informatização (produção toyotista de base informatizada, pluralizada, globalizada). No âmbito político, ocorre o fim da centralização do poder nas mãos dos grandes partidos e instituições. As organizações micrológicas são privilegiadas. O conceito de Estado perde o valor moral e a questão da cidadania e do respeito coletivo é reconceituada, em função de valores individuais e restritivos (ROUANET, 1987). Nas esferas da arte e cultura, as mudanças são mais radicais ainda. "Há um fascínio pela paisagem degradada do brega e do Kitsch" (ECO s.d apud JAMESON, 1996, p. 28). Ocorre a hipervalorização do vídeo (especialmente da TV), que é responsável pelo consumo da maior parte das informações pasteurizadas e seriadas.

Quanto à ciência e à filosofia, há um confronto explícito entre o saber legitimado pelo Iluminsmo moderno e o pragmatismo. O conhecimento prima pela busca de legitimidade em vias opostas à da modernidade, valorizando a heterogeneidade, a diferença, a superficialidade dos gêneros pela anarquia (fim das padronizações) e pela paralogia (registro da impressão imediata do conhecimento). Também o campo da ética sofre alterações bruscas. Rejeitando-se os modelos, tanto da moralidade cristã quanto da moralidade laica e universal, a moralidade pós-moderna privilegia o individualismo. No campo da ciência especificamente (que é o que nos interessa), os avanços tecnocientíficos, apesar de promoverem mudanças radicais, não caracterizam, necessariamente, mudanças significativas no campo das teorias científicas. Os conflitos nessa esfera são decorrentes das variações e proposições metodológicas, que reformulam aquelas impostas pela concepção moderna.

Outra leitura que nos chama à atenção, se bem que amparada por outra ótica, é a do sociólogo português Boaventura de Sousa Santos, que também analisa a pós-modernidade, porém, utiliza-se de argumentos diferentes daqueles propostos por Rouanet e Jameson (1996). Pode-se dizer que sua visão é mais "otimista".

No pequeno livro intitulado Um Discurso sobre as Ciências (SANTOS, 1987), o autor faz uma síntese acerca das teorias científicas constituídas no bojo da ciência contemporânea, deli- 
Pechula, M. R.

neando os novos contornos epistemológicos e sociológicos dessas teorias. Parte do princípio de que vivemos, nos tempos atuais, uma condição ambígua nos campos da ciência e tecnologia. "Em termos científicos, vivemos ainda no século XIX", pois estamos ainda amparados pelas teorias desse século. Mas, "no campo das potencialidades tecnológicas, cremos estar no limiar da comunicação interativa que nos lança para o século XXI” (SANTOS, 1987, p. 6). Em meio a este paradoxo, o autor elabora uma reflexão acerca das possibilidades e limites da natureza diante da rápida exploração humana.

O sociólogo interpreta que a crise que se manifesta na ciência, hoje, é o resultado do projeto iluminista que elegeu a razão científica como a única forma de conhecimento válido e verdadeiro. A supremacia do conhecimento racional e o abandono das especulações axiológicas provocaram um "vazio" nas teorias científicas, que nos faz retornar ao problema que afligia o homem no início da modernidade, qual seja: a necessidade de

perguntar pelas relações entre ciência e virtude, pelo valor do conhecimento dito ordinário ou vulgar que nós, sujeitos individuais ou coletivos, criamos e usamos e que a ciência teima em considerar irrelevante, ilusório e falso; e temos ainda de perguntar pelo papel de todo o conhecimento científico acumulado no enriquecimento ou empobrecimento prático de nossas vidas, ou seja, pelo contributo positivo ou negativo da ciência para a nossa felicidade. (SANTOS, 1987, p. 8-9)

Quanto ao caráter "universal” da ciência, o autor (1987, p. 48-55) afirma que "o conhecimento pós-moderno, sendo total, não é determinístico, sendo local, não é descritivista. É um conhecimento sobre as condições de possibilidade”. Nesse sentido, a metodologia de abordagem no processo do conhecimento não pode e não deve ser unidimensional, uma vez que o objetivo do conhecimento, nessa acepção, não é o de "descobrir, mas sim o de criar". O conhecimento científico, "ressubjetivado, ensina a viver e traduz-se num saber prático".

\section{Ciência e imaginário social}

A "revolução tecnológica" (que se expressa a partir da segunda metade do século $\mathrm{XX}$ ), possibilita amplos avanços da informação, o que torna a divulgação científica mais acessível ao público que excede os limites da universidade. Os meios de comunicação alcançam rapidamente a casa dos ouvintes, telespectadores e consumidores de informática, permitindo um grande trânsito de informações acerca de boa parte das grandes (e das medíocres) descobertas e criações das ciências do mundo atual.

A divulgação das principais descobertas e avanços tecnológicos veiculada pelos meios de comunicação de massa ampara-se na fundamentação científica. Em seu nome, esses meios (televisão, revistas, jornais), divulgam o conhecimento, instigando o imaginário de que a ela cabe a resolução dos problemas, especialmente, daqueles que envolvem a sobrevivência da humanidade, do planeta e do cosmo. Promovem, ainda, o imaginário de que o conhecimento científico é acessível a todos. 
A Ciência nos meios de comunicação de massa:...

Vale ressaltar que a crise teórico-metodológica que envolve o conhecimento científico contemporâneo não está centrada na condição da ciência enquanto um saber, pelo contrário, seu status lhe garante maior credibilidade a partir do momento em que as descobertas científicas começam a ser divulgadas pelos meios de comunicação de massa. Nesse contexto, a ciência passa a viver sob uma nova visão, gerada pelo imaginário social. O termo, na concepção de Diaz (1996), significa a construção de modelos sociais concebidos padronizadamente. "O imaginário social é uma complexa rede de relações entre discursos e práticas sociais [...]" que interage com as individualidades e se constitui com base nas coincidências valorativas das pessoas. "[...] Instala-se nas distintas instituições que compõem a sociedade e atua em todas as instâncias sociais" (p. 13). Nessa perspectiva, o "novo" imaginário científico supera tanto aquele implantado pela ciência medieval (geocentrismo), quanto parte daquele posto pela visão iluminista de que o homem é sujeito e centro do universo (antropocentrismo). Isso significa que o conhecimento torna-se uma propriedade não mais do sujeito (que conhece), mas sim da própria ciência, concebida ora como "entidade", ora como "instituição", capaz de solucionar os problemas humanos e naturais. Esse imaginário é fomentado pelos meios de comunicação de massa (DIAZ, 1996). É nesse sentido que a informação científica, divulgada por esses meios, alimenta o imaginário de que o conhecimento científico é, dentre todos, o mais digno de "crença", aceitação e confiança.

O imaginário social, na análise da autora, é mecanismo que nos permite compreender as condutas das pessoas que aspiram certos ideais ou modelos, considerados dignos de serem seguidos. Esses modelos constituem, então, os seus paradigmas reguladores. No entanto, o valor concebido imageticamente é, ao mesmo tempo, individual e social. Dessa forma, "as idéias reguladoras, como idéias que são", existem tanto na imaginação individual quanto no imaginário coletivo e "produzem materialidade, quer dizer, efeitos na realidade". Por isso, cada indivíduo "se reconhece a si mesmo como uma entidade empírica e psicológica", possuindo uma percepção interna, que configura um "eu". Essa entidade, entretanto, não é suficiente para que o indivíduo possa se formar sozinho, por isso, a relação com o outro é imprescindível para a identidade humana. O imaginário coletivo, então, é fruto dos valores conhecidos e compartilhados numa determinada época. Funciona como parâmetro das condutas, das palavras e das expectativas (DIAZ, 1996). É, nesse sentido, que se pode afirmar que a divulgação científica sustenta um determinado modelo de imaginário social sobre a ciência. Por isso, atualmente, toda e qualquer descoberta e invenção científica, muitas vezes antes mesmo de ser finalizada, vai para os meios de comunicação.

\section{A ciência como informação nos meios de comunicação de massa}

O desenvolvimento dos meios de comunicação de massa (reconhecido como "revolução eletrônica") exige a necessidade de maior compreensão acerca da teoria da informação. Segundo Coelho Netto (1999), na investigação da teoria da informação, o que interessa não é tanto o significado da mensagem, mas, sim, sua capacidade de eliminar dúvidas. Sendo a mensagem a base da preocupação da teoria da informação, ela é concebida como "um grupo ordenado de elementos de percepção extraídos de um repertório e reunidos numa determinada estrutura” (MOLES apud COELHO NETTO, 1999, p. 122). Tal conteúdo deve primar pelo 
Pechula, M. R.

novo e provocar mudança no comportamento do telespectador. Afirma o autor "quanto maior for a taxa de novidade de uma mensagem, maior seu valor informativo, sendo maior a mudança de comportamento provocada" (p. 128). O velho, o já visto, o já conhecido, só servem para a construção da mensagem "cujo único objetivo é a manutenção de um determinado estado, de uma certa situação".

Apesar da pertinência da análise de Coelho Netto (1999), nossa leitura não será centrada nela, pois, tanto a ciência quanto sua divulgação pelos meios de comunicação de massa, estão inseridas num contexto cultural que é alterado, ou mesmo transformado, à medida que novos valores e concepções são construídos socialmente, isto é, coletivamente. Nessa acepção, os conhecimentos e os valores de uma sociedade são reflexos culturais dessa sociedade.

$\mathrm{Na}$ perspectiva da escola de semiótica de extração russa, a cultura "funciona como um sistema de signos" (LOTMAN e USPENSKII, 1981, p. 45). Entretanto, nesse sistema, "a relação com o signo e a signicidade representa uma das características fundamentais da cultura”. Nesse sentido, a cultura não é rígida e imutável. Ao contrário, se forma a partir da construção de textos que se expressam como "realização da cultura". O texto, sendo o material de reconstrução da realidade, constitui a essência da cultura que "logra vencer o esquecimento, transformando-o num dos mecanismos da memória” (p. 46). Dessa forma, o texto tanto preserva a memória, quanto provoca mudanças, gerando novos contextos culturais.

Posto isso, o nosso objetivo, amparado inicialmente na leitura sociológica acerca do imaginário social, se completa com a análise dos signos que se manifestam na divulgação do conhecimento científico, pelos meios de comunicação de massa, como reforço de um imaginário social que oferece uma visão "ingênua" acerca do conhecimento científico. Para atender a este objetivo, analisaremos a comunicação impressa, destacando-se a produção da revista $S u$ perinteressante, cujo segmento é, sobretudo, o de divulgação científica ${ }^{2}$.

A hipótese inicial é a de que os veículos de comunicação de massa, quando se propõem a informar as descobertas e invenções científicas, o fazem em nome do conhecimento científico. Entretanto, ao produzirem a informação acerca da descoberta, ou criação científica, empregam alguns signos que representam o mundo ingênuo, que apresenta a ciência enquanto um conhecimento pronto e solucionador de todos os problemas. Nessa perspectiva, a presença dos signos que promovem um imaginário social ingênuo, coloca este imaginário em confronto com a perspectiva científica elaborada pelas universidades e instituições especializadas.

O motivo de centrar análise num veículo de comunicação de massa deve-se ao fato de que esses veículos ocupam espaço significativo na divulgação do conhecimento científico, sob a forma de informação de notícias. Outra "razão" é a de que tais veículos têm-se tornado cada vez mais atraentes aos olhos dos receptores, que passam, muitas vezes, a preferi-los às formas

\footnotetext{
${ }^{2}$ A análise exposta no texto é um recorte de Pechula (2001), pesquisa para tese de doutorado que fez um levantamento de dados compostos por vários veículos de divulgação científica, dentre eles programas televisivos "As Fronteiras da Ciência" e "Mistérios da Ciência" e as revistas Superinteressante e Galileu. Justificamos que, neste texto, a escolha da revista é decorrente de sua circulação significativa nos meios acadêmico e escolar, nos quais é utilizada, inclusive, como material didático ou paradidático. Os artigos selecionados foram aqueles que consideramos melhor exemplificarem a temática tratada.
} 
A Ciência nos meios de comunicação de massa:...

institucionalizadas de aquisição de conhecimento (tal como as escolas, por exemplo), e que, de certa forma, substituem a recepção da informação científica.

\section{A divulgação científica nos meios de comunicação de massa - o caso da revista Superinteressante}

Umberto Eco, na obra Apocalípticos e Integrados (ECO, s.d, p. 335-7), afirma que a TV não é um gênero, é um "serviço": "um meio técnico de comunicação, através do qual se podem veicular ao público diversos gêneros do discurso comunicativo, cada um dos quais corresponde, não só às leis técnico-comunicativas do serviço, como também às leis típicas daquele dado discurso". Consideramos que essa concepção pode abranger, também, todos os demais veículos de comunicação, tais como o rádio, as revistas e a comunicação on-line, compreendendo, dessa forma, aquilo que concebemos por mídia. A mídia, no conceito estabelecido por Eco, como meio para "servir", ou melhor, para produzir a comunicação, necessita identificar seus receptores, isto é, precisa saber a "quem" ela se dirige e "o que" eles fruem quando se encontram diante dela.

A compreensão dessa concepção exige esclarecimento sobre duas questões: a necessidade de a mídia produzir a informação para comunicar aquilo que deseja; e os mecanismos que ela utiliza para a produção da informação. Partiremos do princípio de que a informação é constituída de linguagem que se expressa por meio dos códigos. Estes, por sua vez, só podem ser compreendidos se inseridos na cultura à qual pertencem. Dessa forma, cada cultura possui um conjunto de códigos específicos para produzir a informação que gera a comunicação.

Informar (do verbo latino informare) significa dar forma, formar, fabricar. A informação da notícia, então, é fabricada, formada, a partir do contexto cultural compreendido socialmente. A indústria da informação, que dá forma à comunicação de massa, produz vasto volume de informações, gerando o fenômeno da "hipermídia" - explosão informacional.

Segundo Siqueira (1999, p. 25), "o papel da informação na sociedade pós-guerra se torna de tal forma relevante que vem à luz o termo sociedade da informação. Nela vive-se cultural, política, científica e, principalmente, economicamente em torno da circulação de informações". Inserida nesse contexto, a ciência é transformada em notícia; e a pesquisa, mesmo que ainda em processo de formulação ou hipótese, é rapidamente divulgada. Contudo, geralmente, é divulgada como descoberta, criação já acabada ou como início de uma descoberta que alcançará o seu intento. O receptor, sem o saber, torna-se consumidor desse tipo de informação que, transformado em notícia, torna-se um fenômeno cotidiano e é consumido como as demais notícias. E, assim como essas, a informação científica não possuirá aprofundamento, detalhes teórico-conceituais, o que impedirá a compreensão mais profunda da informação recebida por parte do telespectador.

A informação adquire, por essa forma, um caráter ideológico, no qual o discurso é proferido em nome do conhecimento científico-racional, que, no entanto, elabora um imaginário que remete o receptor a uma visão ingênua e "encantada" acerca da ciência. A produção da divulgação transforma esse conhecimento em espetáculo. Nesse sentido, a informação construída pela divulgação científica, com o propósito de fomentar o investimento da ciência 
Pechula, M. R.

enquanto um produto que gera a necessidade de consumo de suas descobertas e criações, conduz à alienação do receptor (consumidor).

$\mathrm{Na}$ análise de Morin (1990), a vasta produção de informações dos meios de comunicação de massa provoca um imaginário que recebe a idéia parcializada do real como se esta fosse a realidade total. Esta imagem de totalidade é o reflexo do receptor como consumidor. Por isso, a notícia, quando apresentada, fragmenta o real, extraindo-o de seu contexto mais amplo. Mas isso não é anunciado e provoca um imaginário de que aquela notícia apresentada refere-se à totalidade da realidade, ou seja, condiz a uma verdade inquestionável. Exemplificando, quando se apresenta uma descoberta, como a da cirurgia para redução do estômago em pessoas portadoras de obesidade mórbida, esta é "vendida", exposta como a situação solucionadora de todos os problemas que giram em torno da causa (no caso, a obesidade).

Segundo Bourdieu (1997), os meios de comunicação exercem um poder significativo sobre seus receptores. A televisão "tem uma espécie de monopólio de fato sobre a formação das cabeças de uma parcela muito importante da população" (p. 23). Para tanto, ela sabe lidar, extraordinariamente, tanto com as palavras quanto com as imagens, pois, "paradoxalmente, o mundo da imagem é dominado pelas palavras". Nomear, lembra o autor, "é fazer ver, é criar, levar à existência", por isso as palavras podem produzir "milagres", ideologias (concebidas como representações falsas), crenças, teorias, e são capazes de criar fantasias e medos que podem "causar estragos". A imagem, para esse autor, não possui um poder menor do que as palavras. Ela possui a "particularidade de poder produzir o que os críticos literários chamam de efeito de real, ela pode fazer ver e fazer crer no que faz ver" (p. 28). Na produção da informação pelos meios de comunicação, a palavra, associada à imagem, potencializa a recepção da informação, isto é, desperta o interesse e atenção objetivados no processo de elaboração da notícia, que tem o poder de provocar a confiança e credibilidade do receptor.

Dessa forma, os meios utilizam palavras e imagens "atraentes" para conquistar o receptor. Essa análise pode ser ilustrada com a matéria do encarte especial intitulado "XX o século da ciência", da revista Superinteressante. A matéria, cujo título é "depois de Dolly é a nossa vez", diz o seguinte:

o sucesso da ovelha Dolly, nascida em agosto de 1996, mostrou que já não existe qualquer obstáculo prático que impeça a clonagem de seres humanos. Gente interessada em produzir uma cópia de si mesma não falta e vários cientistas estão na parada pelas glórias dessa proeza. Em dezembro de 1997, o americano Richard Seed, especialista em reprodução humana, anunciou planos de produzir réplicas humanas. Outros logo o imitaram. (SUPERINTERESSANTE, 1999, p. 18)

A matéria alerta para o fato de que a clonagem de mamíferos "é uma tarefa árdua", mas, na seqüência, anuncia: "esses empecilhos podem atrasar o surgimento do primeiro clone humano, mas que ele virá, virá”. O texto, curto e superficial, é complementado por uma foto com uma imagem de várias meninas de, aparentemente, oito anos de idade, idênticas e vestidas iguais, sugerindo a clonagem coletiva. Nossa interpretação é a de que a elaboração do texto, no imaginário coletivo, tece a idéia de que, em breve, o homem dominará a natureza humana, produzindo-a de acordo com o seu planejamento. 
A Ciência nos meios de comunicação de massa:...

A revista Superinteressante, da editora Abril, conta com uma tiragem entre 470 e 480 mil exemplares. Destina-se à informação de novidades e curiosidades históricas, culturais e científicas. Sua ênfase, entretanto, é na ciência, como nos levam a crer suas manchetes de capa, quase que em sua totalidade, voltadas para as descobertas e domínios do conhecimento científico. Outra demonstração de que o objetivo maior da revista é o de divulgação científica é a constituição da capa, que traz, invariavelmente, assuntos abrangentes, tais como: história, religião, sexo, cultura, entre outros, sempre recortados em temáticas científicas. Exemplos: a edição n. 176 (maio/2002): "pedofilia, como a ciência explica o desejo sexual por crianças?"; edição n. 178 (julho/2002): "Bíblia, o que é verdade e o que é lenda - a arqueologia investiga as provas históricas dos relatos bíblicos"; edição n. 182 (novembro/2002): "a ciência de ser saudável, novos estudos mostram que ter saúde é mais fácil e barato do que você imagina"; edição n. 186 (março/2003): "paranormalidade existe? Premonição. Clarividência. Telepatia. Telecinese. O que a ciência diz sobre o que ela não consegue explicar?”.

A revista destina-se a um público abrangente e diversificado. Mas a construção de sua editoração demonstra claramente que Superinteressante dirige-se à informação de um público bem jovem, que, certamente, freqüenta uma instituição educacional (tal como escolas do ensino médio, cursinhos etc).

Outras matérias da revista reforçam a análise empreendida por Bourdieu (1997). A edição de julho/2001 (p. 63-67) traz um artigo sobre clonagem, associando-a à questão da imortalidade. O texto se ampara nos signos da imortalidade e da ressurreição para expor o problema da clonagem, que é apresentada como a garantia de superação das perdas, sobretudo, a perda da vida. A matéria começa anunciando a vasta e "fracassada" tentativa de clonagem humana existente desde o "sucesso" obtido com a ovelha Dolly. Mas, afirma que a clonagem é possível. Descreve as várias tentativas de cientistas norte-americanos, empenhados em um trabalho de pesquisa exaustivo. Esses cientistas acreditam que, em breve, poderão obter o sucesso almejado. A questão, entretanto, segundo o texto, provoca um debate acerca do benefício que a clonagem poderia trazer à humanidade. E um dos benefícios citados é o de promover o retorno de pessoas que já morreram. Segundo o texto "a meta é trazer ao mundo um bebê saudável, o que provavelmente daria ao pesquisador o prêmio Nobel pelo nascimento do primeiro clone humano".

Na seqüência, o artigo descreve o trabalho da equipe da professora de bioquímica, Dra Brigitte Boisselier, empenhada nesse tipo de produção; "o primeiro ser humano que vamos clonar é um bebê de dez meses de idade morto em um acidente"; diz que o pai da criança ajudou a comprar o laboratório onde serão realizadas as pesquisas. E continua a declaração da professora: "e nós vamos ajudá-lo a ter o filho de volta". O texto expõe várias opiniões de cientistas da área, contra e a favor.

Dentre os concordantes, destacamos o depoimento do médico, especialista em reprodução artificial, do hospital Albert Einstein, em São Paulo, Dr. Roger Abdelmassih: "muitos casais que perdem seus filhos em acidentes me procuram, pedindo que eu os ajude a ter outro filho. Principalmente as mães em idade avançada. Se o processo de clonagem já estivesse dominado, não seria lógico dar àqueles casais uma criança com as mesmas características do filho morto?" Esse depoimento pode ser visto somente do ponto de vista lógico. Entretanto, sua repercussão social remete ao imaginário do desejo humano em superar a morte, garantin- 
Pechula, M. R.

do a "vida eterna". Ele expressa o sonho humano de "viver eternamente". Tece a esperança de que, se perdermos um ente querido, poderemos, graças à intervenção da ciência, tê-lo de volta.

Visão semelhante a essa aparece em uma outra matéria, bem anterior à citada acima (NESTLEHNER, 1999, p. 62-67). A manchete diz: "a clonagem pode salvar os animais em extinção e ressuscitar os extintos". E descreve o projeto de uma experiência de clonagem a partir de um feto de tigre da Tasmânia que, há 133 anos, está de "molho num vidro no museu australiano". O texto é produzido com base em depoimentos dos cientistas envolvidos com o projeto e expõe, claramente, os problemas encontrados pelos limites da ciência para alcançar o objetivo almejado. Entretanto, desde a chamada exposta no Sumário e com várias conotações no texto, o referencial aponta para a certeza de que a ciência da clonagem, no futuro, irá solucionar esse tipo de problema. E a extinção das espécies será coisa do passado.

\section{Considerações finais}

As matérias empregadas para exemplificação da problemática tratada no texto, cujos conteúdos foram rapidamente analisados, tratam a informação de forma genérica e homogeneizada. Dificilmente abrem para a polêmica e discussão teórica acerca das divergências e contradições. A informação, geralmente, está impregnada de conceitos, termos (palavras) e fotografias impactantes, que remetem a uma visão espetacularizada, às vezes, até "encantada", e geram o imaginário de crença no conhecimento científico. A ciência, triunfo da razão, é divulgada obedecendo a um método que apela para as palavras e imagens impactantes e espetaculares que, ao mesmo tempo em que banaliza a informação científica, constrói, sobre ela, um imaginário: é a única fonte solucionadora de todos os problemas. E mais, faz parecer que tudo já foi descoberto e resolvido pela ciência, que servirá a todos, indistintamente.

Ora, de acordo com o debate exposto no início, fica claro que há um paradoxo entre a ciência produzida e discutida nas universidades - que passa, continuamente, por um debate amplo e conflituoso, cujos limites são sempre postos em questão pelos próprios cientistas -, e a divulgação dessas descobertas e criações que, ao serem produzidas pelos meios de comunicação, são "revestidas", quase que invariavelmente, de um imaginário mítico-sagrado, no qual o discurso científico racional aparece com uma roupagem mágica, encantada. É essa visão de ciência que entra na vida dos receptores (consumidores) que, sem o saber, consideram a informação recebida como um conteúdo pronto e acabado e passam a viver sob o imaginário ingênuo de que, sob a proteção científica, todos os problemas podem ou poderão ser resolvidos.

A análise permite algumas leituras. A primeira reporta que o discurso predominante sobre a ciência, suas descobertas e criações, ainda está sustentado na concepção moderna, que sobrepõe a razão empírica a todas as demais formas de conhecimento, ao mesmo tempo em que enaltece o seu poder sobre a natureza. Por isso o imaginário é o de que a ciência pode resolver todas as coisas. Esse imaginário, no âmbito social, é ingênuo e desconexo daquele forjado nos centros e instituições de pesquisa. A segunda refere que os signos de apreensão da informação, entretanto, remetem a um imaginário ingênuo que atribui à ciência uma concepção divinizada, mitificada. Isto ocorre porque, no processo de transmissão da informação, a mensagem produz a banalização dos conceitos e a ciência aparece com uma roupagem mágica 
A Ciência nos meios de comunicação de massa:...

e encantada, ocupando o lugar que antes pertencia às religiões. Uma terceira e última leitura é a de que a ciência, uma forma de conhecimento que pertence a uma sociedade, constitui-se em um produto cultural elaborado, também, com a finalidade de melhor compreender a relação entre homem e natureza. Nesse sentido, a recepção da informação científica atende à necessidade humana de compreender, imageticamente, a sua existência, uma vez que o imaginário social, inerente à cultura humana, representa sempre sua forma de conceber o mundo.

\section{Referências}

BOURDIEU, P. Sobre a Televisão. Trad. Maria L. Machado, Rio de Janeiro: Jorge Zahar, 1997.

BUICAN, D. Darwin e o darwinismo. Trad. Lucy Magalhães. Rio de Janeiro: Jorge Zahar, 1990.

COELHO NETTO, J. T. Semiótica, informação e comunicação. 5. ed. São Paulo: Perspectiva, 1999.

DARWIN, C. A origem das espécies. Trad. Eduardo Fonseca. São Paulo: Hemus, 1981.

DÍAZ, E. (Org.). La Ciencia y il imaginario social. Buenos Aires: Biblos, 1996.

ECO, U. Apocalípticos e integrados. 2. ed. São Paulo: Perspectiva, s.d.

GLEISER, M. A dança do universo, dos mitos de criação ao big-bang. São Paulo: Companhia das Letras, 1997.

HAWKING. S.; MLODINOW, L. Uma nova história do tempo. Trad. Vera de Paula Assis. Rio de Janeiro: Ediouro, 2005.

JAMESON, F. Pós-modernismo: a lógica cultural do capitalismo tardio. Trad. Maria Elisa Cevasco. São Paulo: Ática, 1996.

JAMMER, M. Einstein e a religião - física e teologia. Trad. Vera Ribeiro. Rio de Janeiro: Contraponto, 2000.

MORIN, E. Cultura de massa no século XX. 8. ed. Rio de Janeiro: Forense Universitária, 1990.

NESTLEHNER, W. O fim da extinção. Superinteressante, São Paulo, v. 13, n. 12, p. 62-67, 1999.

PECHULA, M. R. Os signos mítico-sagrados no discurso científico racional: análise da divulgação científica nos meios de comunicação de massa. 2001. Tese (Doutorado) Programa de Comunicação e Semiótica, Pontifícia Universidade Católica de São Paulo, São Paulo. 
Pechula, M. R.

ROUANET, S. P. As razões do Iluminismo. São Paulo: Companhia das Letras, 1987.

SANTOS, B. S. Um discurso sobre as ciências. 12. ed. Porto: Afrontamento, 1987.

STANGERS. I. La Guerre des Sciences. Paris: La Découverte, 1996.

SUPERINTERESSANTE. XX o século da ciência. Depois da Dolly é a nossa vez. São Paulo, n. 2, 1999. Suplemento especial.

SIQUEIRA, D. C. A ciência na televisão: mito, ritual e espetáculo. São Paulo: Annablume, 1999.

VOMERO, M. F. Homens em série. Superinteressante, São Paulo, ano 15, n. 7, p. 63-67, 2001.

Artigo recebido em novembro de 2006 e aceito em julho de 2007. 